\title{
First occurrence of Anodontites tenebricosus (Bivalvia: Mycetopodidae) in the Tocantins-Araguaia basin, Brazil
}

\author{
C. T. Puppin-Gonçalves ${ }^{a *}$, L. X. S. Tenório ${ }^{a}$, A. B. Neiva ${ }^{a}$ and M. J. Martins-Silva ${ }^{a}$ \\ ${ }^{a}$ Laboratório de Bentos, Departamento de Zoologia, Instituto de Ciências Biológicas, \\ Universidade de Brasília - UnB, CEP 70910-900, Brasília, DF, Brazil \\ *e-mail: carolpuppin@gmail.com
}

Received: May 22, 2015 - Accepted: July 20, 2015 - Distributed: November 30, 2016

(With 1 figure)

Anodontites tenebricosus (Lea, 1834) typically inhabits lotic environments, partially buried in sandy or gravel substrate in South America waters (Bonetto, 1967; Castellanos and Landoni, 1990). The species occurs in four Neotropical sub-regions, and, in Brazil, it has been mostly found in the Paraná basin (Mansur and Pereira, 2006; Graf and Cummings, 2007; Bogan and Cummings, 2011; Troncon and Avelar, 2011).

The Tocantins-Araguaia basin occupies $10.8 \%$ of Brazil, and reaches five Brazilian states and Distrito Federal. The Tocantins River rises in Goiás state, Central Brazil, and its superior course is formed by two main tributaries, the rivers Maranhão and Paranã. Nowadays, the water pumping for agriculture and industry uses are the mainly applications of the basin, turning critical the balance between water availability and its demand (ANA, 2013).

The field work was carried out at the Paranã River (14 46' 17.89' S - 47 20'18.68' W), on the surroundings of Alto Paraíso de Goiás, Goiás state (see Figure 1). The bivalves were collected by fishing net in September 2008 , by the end of the dry season. A complete individual and three valves were identified and deposited in the Mollusk Collection of University of Brasília (lot numbers CMUnB 417 and CMUnB 429).

According to Pereira et al. (2013), A. tenebricosus occurs principally at the lower countries of South America, being recorded in the Uruguay, Plata and Paraná basins, with its frequency decreasing northwards (Pereira et al., 2013). Simone (2006) estimates its distribution along all South-American basins westerly to Andes, however, there was no record of the species in the Tocantins-Araguaia basin until now, and the Venezuelan register for the Orinoco river delta shows no connection to this hydrographic region.

The Brazilian inland aquatic ecosystems are in real danger. For the range of Tocantins-Araguaia basin, the main threats to the freshwater biodiversity are poor water treatment, deforestation, construction of dams and canals, intensive cattle ranching and predatory fisheries (Tundisi, 2003). Most of these are pointed as the causes of local extirpation and extinction of many endemic species of freshwater mussels (Bogan, 1993). The Brazilian Ministry of Environment (MMA) classified A. tenebricosus as

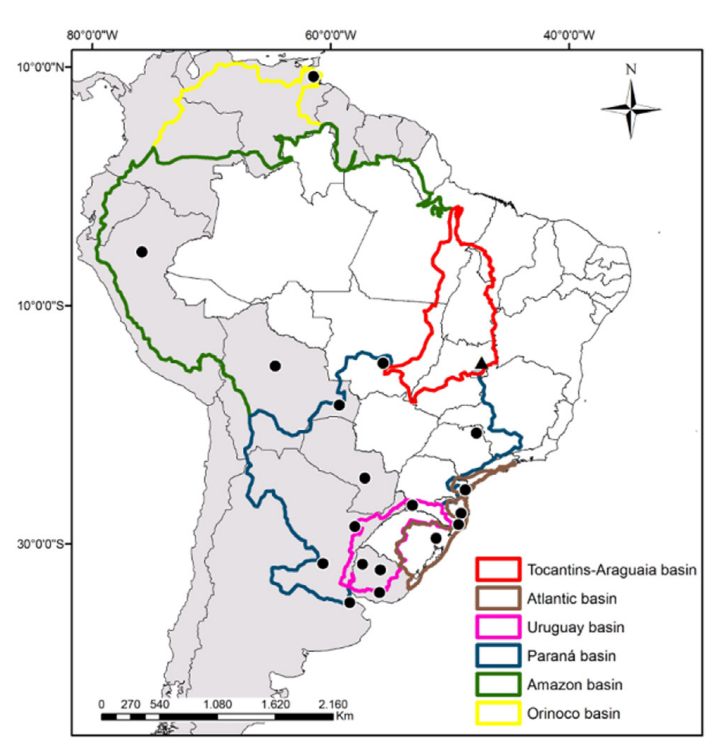

Figure 1. Map of the distribution of Anodontites tenebricosus in South America. The circles $(\bullet)$ represent the regions with the species occurrence and the triangle $(\boldsymbol{\Delta})$ the new register in the Tocantins-Araguaia basin.

"Vulnerable" (Amaral et al., 2008), but the IUCN ranks it as "Least Concern" (Bogan and Cummings, 2011). Therefore, this divergent situation urgently requires studies on freshwater mussels in the country.

The new record of $A$. tenebricosus in the headwaters of the Tocantins River may be a sign that it can be found along the Tocantins-Araguaia basin, and this new-found data is an incentive for further fieldwork at the region. The biological and ecological features of the animal, as well as its relation with fishermen and other communities, must be investigated.

\section{Acknowledgements}

We are grateful to Dr. Maria Cristina D. Mansur for the species taxonomic confirmation and to MSc. Lais F. O. Lima for the paper's contributions. 


\section{References}

AGÊNCIA NACIONAL DE ÁGUAS - ANA, 2013 [viewed 22 May 2015]. Conjuntura dos recursos hídricos no Brasil [online]. Brasília: ANA. 32 p. Available from: http://www.ana.gov.br

AMARAL, A.C.Z., RIBEIRO, C.V., MANSUR, M.C.D., SANTOS, S.B., AVELAR, W.E.P., MATTHEWS-CASCON, H., LEITE, F.P.P., MELO, G.A.S., COELHO, P.A., BUCKUP, G.B., BUCKUP, L., VENTURA, C.R.R. and TIAGO, C.G., 2008. Invertebrados aquáticos. In: A.B.M. MACHADO, G.M. DRUMMOND and A.P. PAGLIA, eds. Livro vermelho da fauna brasileira ameaçada de extinção. Brasília: Ministério do Meio Ambiente, vol. 1, 293 p.

BOGAN, A.E. and CUMMINGS, K., 2011 [viewed 22 May 2015]. The IUCN Red List of Threatened Species: Anodontites tenebricosus. Version 2014.3 [online]. Available from: http:// www.iucnredlist.org

BOGAN, A.E., 1993. Freshwater bivalve extinctions (Mollusca: Unionoida): a search for causes. American Zoologist, vol. 33, no. 6, pp. 599-609. http://dx.doi.org/10.1093/icb/33.6.599.

BONETTO, A.A., 1967. El género Anodontites Bruguière (Mollusca, Pelecypoda) en el sistema hidrográfico del Plata. Physis (Rio de Janeiro, Brazil), vol. 26, no. 73, pp. 459-467.

CASTELLANOS, Z. and LANDONI, N., 1990. La familia Mycetopodidae Gray, 1840 en la Republica Argentina. In: R.A. RINGUELET, ed. Fauna de agua dulce de la Republica Argentina. Buenos Aires: FECIC, vol. 16, pp. 1-86.
GRAF, D.L. and CUMMINGS, K.S., 2007. Review of the systematics and global diversity of freshwater mussel species (Bivalvia: Unionoida). The Journal of Molluscan Studies, vol. 73, no. 4, pp. 291-314. http://dx.doi.org/10.1093/mollus/eym029.

MANSUR, M.C.D. and PEREIRA, D., 2006. Bivalves límnicos da bacia do rio dos Sinos, Rio Grande do Sul (Bivalvia, Unionoida, Veneroida e Mytiloida). Revista Brasileira de Zoologia, vol. 23, no. 4, pp. 1123-1147. http://dx.doi.org/10.1590/S010181752006000400021 .

PEREIRA, D., MANSUR, M.C.D., DUARTE, L.D.S., OLIVEIRA, A.S., PIMPÃO, D.M., CALLIL, C.T., ITUARTE, C., PARADA, E., PEREDO, S., DARRIGRAN, G., SCARABINO, F., CLAVIJO, C., LARA, G., MIYAHIRA, I.C., RODRIGUEZ, M.T.R. and LASSO, C., 2013. Bivalve distribution in hydrographic regions in South America: historical overview and conservation. Hydrobiologia, vol. 735 , no. 1 , pp. $15-44$

SIMONE, L.R.L., 2006. Land and freshwater molluscs of Brazil. São Paulo: FAPESP. 390 p.

TRONCON, E.K. and AVELAR, W.E.P., 2011. A new occurrence of Anodontites tenebricosus (Bivalvia: Mycetopodidae) in the Sapucai river basin, São Paulo, Brazil: environmental and conchological aspects. Brazilian Journal of Biology $=$ Revista Brasileira de Biologia, vol. 71, no. 3, pp. 629-637. http://dx.doi.org/10.1590/ S1519-69842011000400007. PMid:21881786.

TUNDISI, J.G., 2003. Água no século XXI: enfrentando a escassez. São Carlos: RIMA. 247 p 